OPEN ACCESS

Edited by:

Vijai Kumar Gupta,

National University of Ireland Galway,

Ireland

Reviewed by:

Guilherme Lanzi Sassaki,

Universidade Federal do Paraná, Brazil

Alejandro De Las Penas,

Instituto Potosino de Investigación

Científica y Tecnológica, Mexico

*Correspondence:

Arturo Vera-Ponce de León avera@ccg.unam.mx

Specialty section

This article was submitted to Fungi and Their Interactions,

a section of the journal

Frontiers in Microbiology

Received: 14 March 2016

Accepted: 02 June 2016

Published: 23 June 2016

Citation:

Vera-Ponce de León A,

Sanchez-Flores A, Rosenblueth $M$ and Martínez-Romero E (2016) Fungal

Community Associated with

Dactylopius (Hemiptera: Coccoidea:

Dactylopiidae) and Its Role in Uric Acid

Metabolism. Front. Microbiol. 7:954.

doi: 10.3389/fmicb.2016.00954

\section{Fungal Community Associated with Dactylopius (Hemiptera: Coccoidea: Dactylopiidae) and Its Role in Uric Acid Metabolism}

\author{
Arturo Vera-Ponce de León ${ }^{1 *}$, Alejandro Sanchez-Flores ${ }^{2}$, Mónica Rosenblueth ${ }^{1}$ and \\ Esperanza Martínez-Romero ${ }^{1}$
}

' Programa de Ecología Genómica, Centro de Ciencias Genómicas, Universidad Nacional Autónoma de México, Cuernavca, Mexico, ${ }^{2}$ Unidad de Secuenciación Masiva y Bioinformática, Instituto de Biotecnología, Universidad Nacional Autónoma de México, Cuernavca, Mexico

We studied fungal species associated with the carmine cochineal Dactylopius coccus and other non-domesticated Dactylopius species using culture-dependent and -independent methods. Thirty seven fungi were isolated in various culture media from insect males and females from different developmental stages and Dactylopius species. 26S rRNA genes and ITS sequences, from cultured fungal isolates revealed different species of Cryptococcus, Rhodotorula, Debaryomyces, Trametes, and Penicillium, which are genera newly associated with Dactylopius. Uric acid (UA) and uricase activity were detected in tissues extracts from different insect developmental stages. However, accumulation of high UA levels and low uricase activities were found only after antifungal treatments, suggesting an important role of fungal species in its metabolism. Additionally, uricolytic fungal isolates were identified and characterized that presumably are involved in nitrogen recycling metabolism. After metagenomic analyses from $D$. coccus gut and hemolymph DNA and from two published data sets, we confirmed the presence of fungal genes involved in UA catabolism, suggesting that fungi help in the nitrogen recycling process in Dactylopius by uricolysis. All these results show the importance of fungal communities in scale insects such as Dactylopius.

Keywords: fungal-metagenomics, Cryptococcus, scale insects, Rhodotorula, ITS region, purine metabolism, carmine cochineal

\section{INTRODUCTION}

Insects are the most diverse arthropods in the biosphere and dwell in almost all environments. They can feed on a wide variety of nutrients, probably due to their associated microorganisms, including fungal species (Douglas, 2009). There is evidence that many arthropods harbor yeast-like microorganisms inside their bodies (Buchner, 1965), and at least eight orders of insects, including 143 species, have been reported to be associated with fungi (Vega and Blackwell, 2005; Gibson and Hunter, 2010). Fungi are located either inside the insect body in highly specialized cells called mycetocytes, as in Nilaparvata lugens and Drosophila melanogaster, which harbor yeasts (Chen et al., 1981; Ebbert et al., 2003), or in cavities named mycangia as in bark beetles (Jones et al., 1999; Klepzig and Six, 2004; Ganter, 2006). Fungi have also been found in the insect gut, as well as in their 
reproductive organs and fat tissues (Buchner, 1965; Gibson and Hunter, 2009; Rivera et al., 2009; Ricci et al., 2011). Moreover, studies on fungi-insect symbioses show that fungi play important roles in insect development and fitness (Gibson and Hunter, 2010). Fungi are capable of providing nitrogen compounds that are limited in the diets of some insects, or can degrade high molecular weight molecules and produce pheromones for mating and communication (Brand et al., 1976; Sasaki et al., 1996; Nasir and Noda, 2003; Gibson and Hunter, 2010). In some insects like cockroaches, termites, shield bugs, planthoppers, and bark beetles uric acid (UA), the major product of nitrogen excretion, is recycled by bacterial or fungal symbionts (Mullins and Cochran, 1975; Potrikus and Breznak, 1981; Pant, 1988; Kashima et al., 2006; Morales-Jiménez et al., 2013; Patiño-Navarrete et al., 2014). However, to our knowledge, there are no reports on the UA content or catabolism in scale insects.

The Dactylopiidae family includes only one genus, Dactylopius (Costa), commonly called "cactus cochineals" or "cochineal scale insects." They are obligate phytophagous hemipterous from the scale insects family (Coccoidea). Ten species have been described as belonging to this genus and six of them, D. ceylonicus, D. confusus, D. opuntiae, D. coccus, D. bassi, and D. tomentosus, inhabit Mexico (Ben-Dov and Marotta, 2001; Chávez-Moreno et al., 2009). These insects are the main source of carminic acid, a glycoside-anthraquinone molecule used in the textile, cosmetic, pharmaceutical, and food industries as a dye or pigment (Deveoglu et al., 2011). All of these Dactylopius species produce carminic acid, but only $D$. coccus is cultivated and used for commercial purposes due to the higher amount and quality of its pigment (Rodríguez et al., 2005). Moreover, since non-cultivated Dactylopius are considered a cactus plague, in some countries they are used as biological control for these plants (Zimmermann and Moran, 1991; Spodek

TABLE 1 | Collection sites of Dactylopius species.

\begin{tabular}{|c|c|c|c|}
\hline Location & $\begin{array}{l}\text { Location } \\
\text { code }\end{array}$ & Latitude/Longitude & Insect species \\
\hline \multirow{2}{*}{$\begin{array}{l}\text { Campo Carmín, Xochitepec, } \\
\text { Morelos state }\end{array}$} & $\mathrm{CC}$ & $18^{\circ} 44^{\prime} 46.7^{\prime \prime} \mathrm{N}$ & D. coccus \\
\hline & & $99^{\circ} 11^{\prime} 17.8^{\prime \prime} \mathrm{W}$ & \\
\hline \multirow[t]{2}{*}{ Teotihuacán, Mexico state } & TEM & $19^{\circ} 40^{\prime} 47.3^{\prime \prime} \mathrm{N}$ & D. opuntiae \\
\hline & & $98^{\circ} 50^{\prime} 59.4^{\prime \prime} \mathrm{W}$ & \\
\hline \multirow[t]{2}{*}{ Ecatepec, Mexico state } & ECM & $19^{\circ} 35^{\prime} 27.3^{\prime \prime} \mathrm{N}$ & D. opuntiae \\
\hline & & $98^{\circ} 59^{\prime} 57.5^{\prime \prime} \mathrm{W}$ & \\
\hline \multirow[t]{2}{*}{ Jiutepec, Morelos state } & $\mathrm{JM}$ & $18^{\circ} 53^{\prime} 52.5^{\prime \prime} \mathrm{N}$ & D. opuntiae \\
\hline & & $99^{\circ} 10^{\prime} 56.8^{\prime \prime} \mathrm{W}$ & \\
\hline \multirow[t]{2}{*}{ Coyoacán, Federal district } & CDF & $19^{\circ} 19^{\prime} 18.9^{\prime \prime} \mathrm{N}$ & D. confusus \\
\hline & & $99^{\circ} 11^{\prime} 09.8^{\prime \prime} \mathrm{W}$ & \\
\hline \multirow[t]{2}{*}{ Milpalta, Federal district } & MADF & $19^{\circ} 12^{\prime} 26.7^{\prime \prime} \mathrm{N}$ & D. confusus \\
\hline & & $99^{\circ} 1^{\prime} 28.8^{\prime \prime} \mathrm{W}$ & \\
\hline
\end{tabular}

et al., 2013; Pérez-Ramirez et al., 2014; da Silva Santos et al., 2015).

Dactylopius cochineals spend their life feeding on Opuntia and Nopalea cactus sap (Chávez-Moreno et al., 2009), which is mainly composed of water (88-95\% wet weight) and has low protein concentration (0.5-1\% wet weight; Stintzing and Carle, 2005). Thus, we supposed that nitrogen deficiencies may be supplied by associated symbiotic microorganisms. The diversity of microbial symbionts in Dactylopius has been scarcely described. There are a few reports of the bacterial communities in Dactylopius species (Pankewitz et al., 2007; Ramírez-Puebla et al., 2010, 2015). However, there are no reports on the fungal community and their possible roles in association with this cochineal insect. The aim of this work was to identify and describe fungi from diverse stages and tissues of Dactylopius species, as well as to determine their role in uric acid catabolism in these insects.

\section{MATERIALS AND METHODS}

\section{Insect Sampling and Identification}

Dactylopius coccus samples were obtained from Campo Carmín Company (Table 1). Wild species of Dactylopius (D. opuntiae and $D$. confusus) were collected from three states in Mexico (Table 1). Insects were obtained from Opuntia spp. cactus and were transported together with their host plants to the laboratory. For species identification, ten female adults from the different locations were preserved in fixation buffer (chloroform: ethanol: glacial acetic acid 4:3:1). The superficial wax was removed by placing the insects in $10 \% \mathrm{KOH}$ for $10 \mathrm{~min}$ at $60^{\circ} \mathrm{C}$. Body contents were removed by cutting a slit in the body margin and expelling the contents with a spatula. Cleaned specimens were transferred into $70 \%$ alcohol for $10 \mathrm{~min}$. Then, all specimens were transferred and kept in a staining solution ( $2 \%$ aqueous solution of acid fuchsin) overnight. Specimens were washed in $70 \%$ alcohol for $10 \mathrm{~min}$ and dehydrated in $100 \%$ alcohol for $10 \mathrm{~min}$. Each specimen was placed face down on a slide with a drop of Canada balsam and covered with a slip. Microscopic observations with the keys described by Perez-Guerra and Kosztarab allowed the morphological identification of Dactylopius species (PerezGuerra and Kosztarab, 1992). Specimens were deposited in the collection of Héctor González-Hernández from COLPOS, Mexico.

\section{Fungal Isolation, DNA Extraction, and PCR Amplification}

Insects from 1st instar nymph, 2nd instar nymph and adult stages of $D$. coccus and of wild Dactylopius (D. opuntiae and D. confusus) were detached from their host plant, submerged in $100 \%$ ethanol and the wax cover was removed with forceps under a stereoscope. They were then surface disinfected with $70 \%$ ethanol and rinsed twice with sterile water. A pool of five washed and disinfected insects from each developmental stage mentioned above of $D$. coccus, D. opuntiae, D. confusus and a pool of $20 \mathrm{D}$. coccus adult males were totally macerated (hereafter named as whole body samples) with a sterile Eppendorf ${ }^{\circledR}$ pestle in a 1.5 microtube with $500 \mu \mathrm{l}$ of $0.85 \% \mathrm{NaCl}$. Additionally, two 


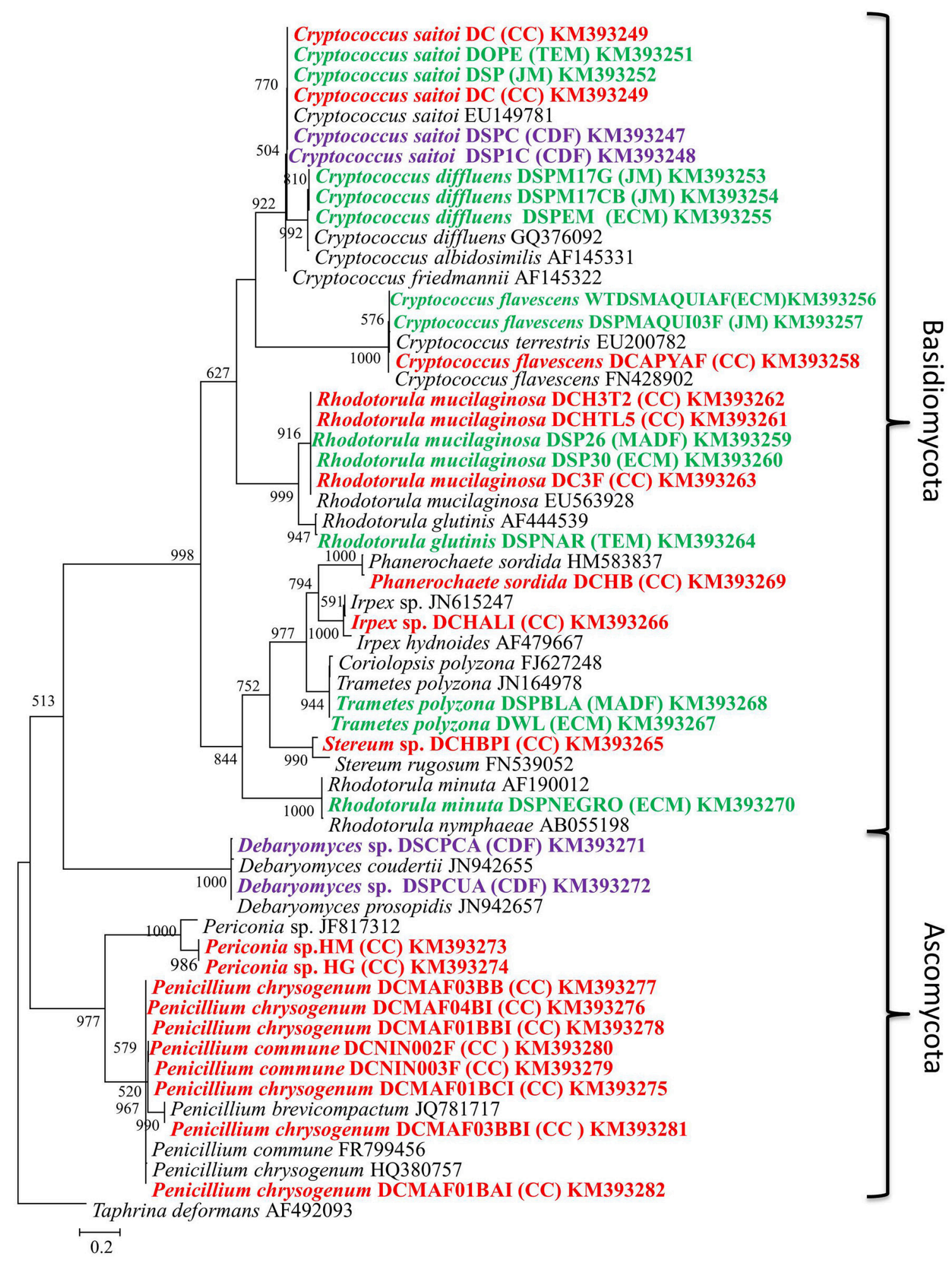

FIGURE 1 | Maximum likelihood tree (-In L = -5579.17063) of fungi isolated from different species of Dactylopius spp. The ITS sequence of Taphrina deformans was used as outgroup. Scale bar indicates $2 \%$ estimated sequence divergence. Bootstrap support values $\geq 50 \%$ are indicated. Colors mean different Dactylopius species. Red, D. coccus; green, D. opuntiae; and purple, D. confusus. Letters in parentheses show the collect site (Table 1). 
TABLE 2 | Fungi associated with different Dactylopius species in culture-dependent analysis.

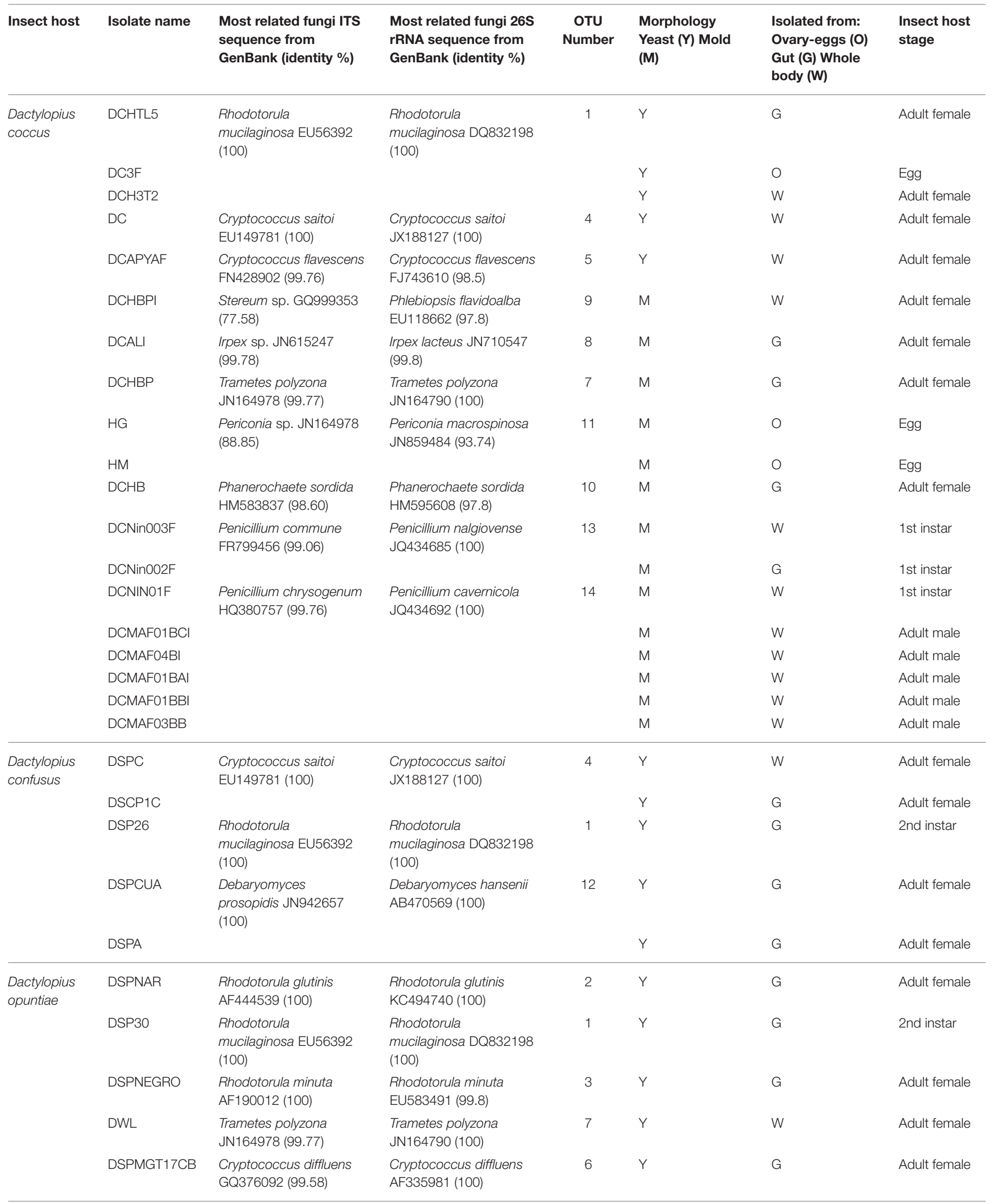


TABLE 2 | Continued

\begin{tabular}{|c|c|c|c|c|c|c|c|}
\hline Insect host & Isolate name & $\begin{array}{l}\text { Most related fungi ITS } \\
\text { sequence from } \\
\text { GenBank (identity \%) }\end{array}$ & $\begin{array}{l}\text { Most related fungi } 26 \mathrm{~S} \\
\text { rRNA sequence from } \\
\text { GenBank (identity \%) }\end{array}$ & $\begin{array}{l}\text { OTU } \\
\text { Number }\end{array}$ & $\begin{array}{l}\text { Morphology } \\
\text { Yeast (Y) Mold } \\
\text { (M) }\end{array}$ & $\begin{array}{l}\text { Isolated from: } \\
\text { Ovary-eggs (O) } \\
\text { Gut (G) Whole } \\
\text { body (W) }\end{array}$ & $\begin{array}{l}\text { Insect host } \\
\text { stage }\end{array}$ \\
\hline & DSPEM & & & & Y & $G$ & 2nd instar \\
\hline & DSPM17G & & & & Y & $G$ & Adult female \\
\hline & DOP & $\begin{array}{l}\text { Cryptococcus saitoi } \\
\text { EU149781 (100) }\end{array}$ & $\begin{array}{l}\text { Cryptococcus saitoi } \\
\text { JX188127 (100) }\end{array}$ & 4 & Y & W & Adult female \\
\hline & DSP & & & & Y & W & 1st instar \\
\hline & WTDSMAQUIAF & $\begin{array}{l}\text { Cryptococcus flavescens } \\
\text { FN428902 (100) }\end{array}$ & $\begin{array}{l}\text { Cryptococcus flavescens } \\
\text { FJ743610 (98.5) }\end{array}$ & 5 & Y & $G$ & Adult female \\
\hline & DSPMAQUI03F & & & & Y & $G$ & Adult female \\
\hline & DSPBLA & $\begin{array}{l}\text { Trametes polyzona } \\
\text { JN164978 (99.77) }\end{array}$ & $\begin{array}{l}\text { Trametes polyzona } \\
\text { JN164790 (100) }\end{array}$ & 7 & M & $G$ & Adult female \\
\hline
\end{tabular}

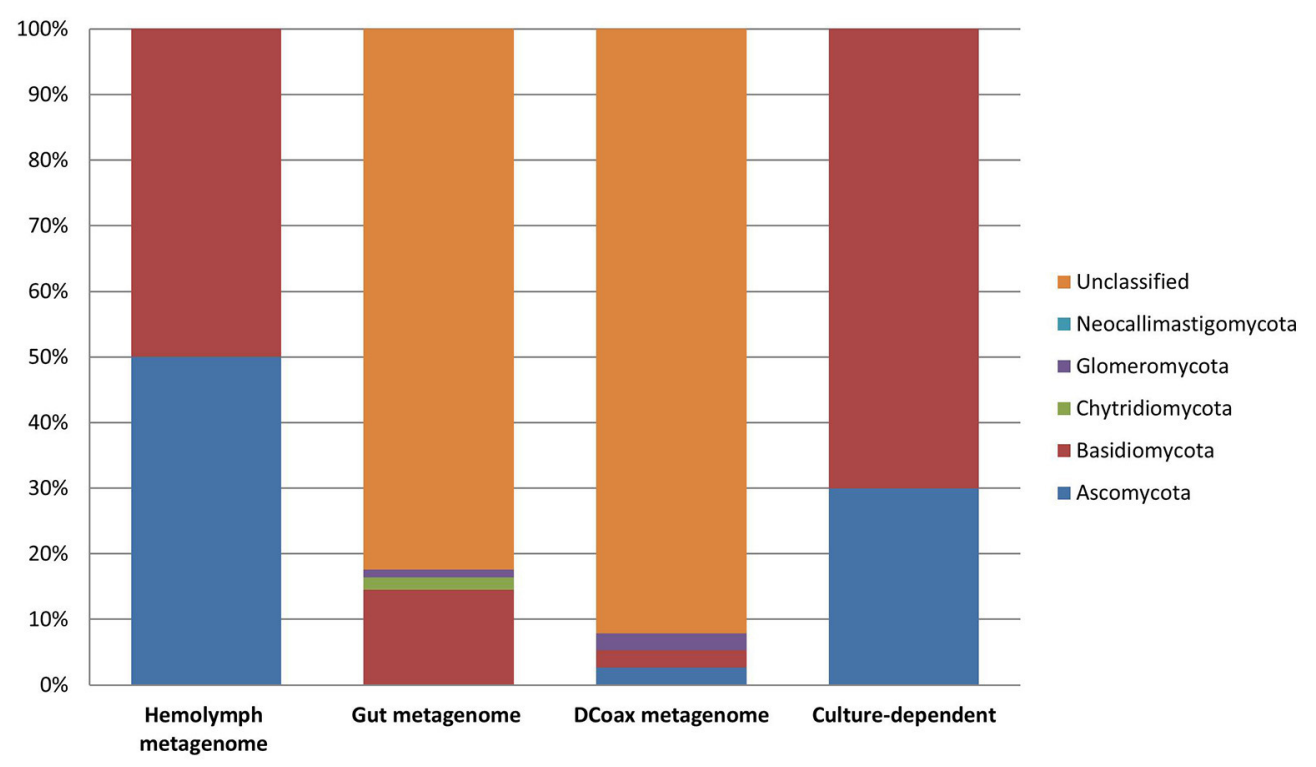

FIGURE 2 | Fungal composition assessed by taxonomic classification of ribosomal rRNA markers from metagenomic (culture-independent) and culture-dependent analyses of $D$. coccus.

individuals of 2 nd instar nymphs and adult females from $D$. coccus, D. opuntiae, and D. confusus were dissected under sterile conditions to obtain guts (gut samples) and ovary-eggs (ovary samples). Dissections were performed by making a transverse cut in the cuticle and removing the organs with fine sterile forceps. These organs were submerged in $600 \mu \mathrm{l}$ of sterile $0.85 \%$ $\mathrm{NaCl}$ and macerated using sterile pestles. After maceration, all samples were indirectly sonicated for $30 \mathrm{~s}$ in a Bransonic ${ }^{\circledR}$ Ultrasonic MH Cleaning Bath. One hundred microliters of this suspension were inoculated in $50 \mathrm{ml}$ of YPD media ( $1 \% \mathrm{w} / \mathrm{v}$ yeast extract, $2 \% \mathrm{w} / \mathrm{v}$ peptone, and $2 \% \mathrm{w} / \mathrm{v}$ dextrose), malt extract

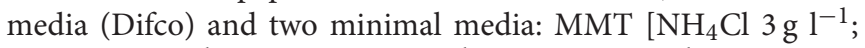
$\mathrm{K}_{2} \mathrm{HPO}_{4} 1 \mathrm{~g} \mathrm{l}^{-1} ; \mathrm{MgSO}_{4} 0.025 \mathrm{gl}^{-1} ; \mathrm{CaCl}_{2} 0.25 \mathrm{gl}^{-1} ; \mathrm{KCl} 0.025 \mathrm{~g}$ $\mathrm{l}^{-1} ; \mathrm{FeSO}_{4} 0.02 \mathrm{~g} \mathrm{l}^{-1}$; yeast extract (Difco) $0.02 \mathrm{~g} \mathrm{l}^{-1}$; trehalose
$0.01 \mathrm{~g} \mathrm{l}^{-1}$; glucose $10 \mathrm{~g} \mathrm{l}^{-1}$; and sucrose $5 \mathrm{~g} \mathrm{l}^{-1}$ ] and MMTC $\left[\mathrm{NH}_{4} \mathrm{Cl} 3 \mathrm{~g} \mathrm{l}^{-1} ; \mathrm{K}_{2} \mathrm{HPO}_{4} 1 \mathrm{~g} \mathrm{l}^{-1} ; \mathrm{MgSO}_{4} 0.025 \mathrm{~g} \mathrm{l}^{-1} ; \mathrm{CaCl}_{2}\right.$ $0.25 \mathrm{~g} \mathrm{l}^{-1} ; \mathrm{KCl} 0.025 \mathrm{~g} \mathrm{l}^{-1} ; \mathrm{FeSO}_{4} 0.02 \mathrm{~g} \mathrm{l}^{-1} ; \mathrm{CuSO}_{4} 0.02 \mathrm{~g} \mathrm{l}^{-1}$; yeast extract (Difco) $0.02 \mathrm{~g} \mathrm{l}^{-1}$; Carmine dye $0.01 \mathrm{~g} \mathrm{l}^{-1}$ (Merck microscopy grade) $]$ and were incubated at $25 \pm 2{ }^{\circ} \mathrm{C}$ at $180 \mathrm{rpm}$ for $72 \mathrm{~h}$. After the incubation period, $100 \mu \mathrm{l}$ of the liquid medium was spread on the corresponding solid medium for selection of yeast and filamentous isolates. To test the best conditions for growing fungi, $100 \mu l$ of the initial macerate suspension was also spread directly on solid media MMTC and MMT and incubated in $\mathrm{CO}_{2}$ generation Gaspack ${ }^{\mathrm{TM}} \mathrm{EZ} \mathrm{CampyPuch}{ }^{\mathrm{TM}}$ System at room temperature for 1 week. Pure cultures were obtained and stored at $-70^{\circ} \mathrm{C}$ in $25 \%$ glycerol for further analysis. 
<smiles>O=c1[nH]c(=O)c2[nH]cnc2[nH]1</smiles><smiles></smiles><smiles>O=C1N=NC2(O)NC(O)=NC(=O)C2(O)N1</smiles>

5-Hydroxyisourate<smiles>NC(=O)NC(NC(=O)C(NC(N)=O)NC(N)=O)C(=O)O</smiles>

Allantoic acid

Allantoin<smiles>[CH]1CC1</smiles>

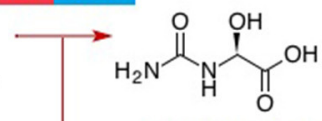

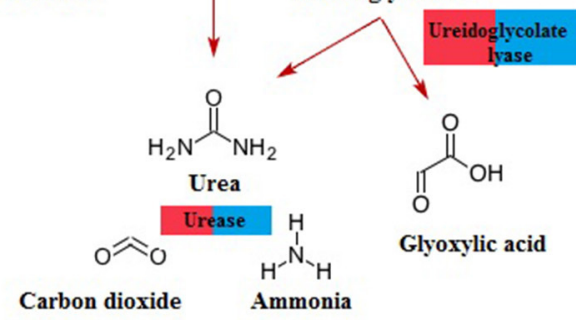

FIGURE 3 | Pathway for purine catabolism of fungal genes predicted from $D$. coccus gut (blue) and hemolymph (red) metagenomes.

DNA from fungal isolates was extracted following the protocols described by Hoffman and Winston (1987). ITS regions were amplified using primers ITS1 (5' TCCGTAGGTGAACCT GCGG $3^{\prime}$ ) and ITS2 (5'TCCTCCGCTTATTGATATGC $3^{\prime}$ ) that we designed for this study. D1-D2 26S rRNA gene region from fungal isolates were amplified using primers 26S-A1 (5' CAT ATCAATAAGCGGAGCAAAAG $3^{\prime}$ ) and 26S-A2 (5' iCAGTTC TGCTTACCAAAAATGG 3'; Scorzetti et al., 2002). The final concentration for $50 \mu \mathrm{l}$ PCR reactions was as follows: $10 \mathrm{ng}$ of total DNA, $0.8 \mathrm{pmol}$ of each primer, $0.2 \mathrm{mM}$ dNTPs, $2.5 \mathrm{mM}$ $\mathrm{MgCl}, 0.5 \mathrm{U}$ Taq polymerase and $1 \mathrm{x}$ Taq polymerase buffer (Invitrogen Life Technologies, Sao Paulo, Brazil). The reaction conditions were $94^{\circ} \mathrm{C}$ for $5 \mathrm{~min} ; 35$ cycles of $60 \mathrm{~s}$ at $94^{\circ} \mathrm{C}, 60 \mathrm{~s}$ at $57^{\circ} \mathrm{C}$, and $90 \mathrm{~s}$ at $72^{\circ} \mathrm{C}$; and a final extension at $72^{\circ} \mathrm{C}$ for $10 \mathrm{~min}$. PCR products were purified using the High Pure PCR Product Purification Kit (Roche) and sequenced by Macrogen Inc. (Seoul, Korea) by Sanger technology.

\section{Insect DNA Extraction}

For shotgun metagenomic analysis, 30 adult females of $D$. coccus were externally disinfected and dissected as described above. All 30 guts (including the Malpighian tubules) were placed in $200 \mu \mathrm{l}$ of lysis buffer solution (Tris- $\mathrm{HCl} 10 \mathrm{mM}, \mathrm{pH}$. 8; EDTA $1 \mathrm{mM}$;
$\mathrm{NaCl} 10$ mM; SDS 1\%; Triton X-100 2\%). For DNA extraction, samples were macerated with sterile pestles, additionally $0.3 \mathrm{~g}$ of sterile glass beads and $200 \mu \mathrm{l}$ of phenol-chloroform-isoamyl alcohol $(25: 24: 1)$ were added to the macerate. The samples were mixed by vortexing, warmed at $65^{\circ} \mathrm{C}$ for $1 \mathrm{~h}$, followed by centrifugation at $15996 \times \mathrm{g}$ and the aqueous phase was recovered. Nucleic acids were precipitated with $1 \mathrm{ml}$ of absolute ethanol for $20 \mathrm{~min}$ at $-20^{\circ} \mathrm{C}$, washed twice with $70 \%$ ethanol then dried in a vacuum concentrator, resuspended in $50 \mu \mathrm{l}$ of deionized water and cleaned with DNeasy Blood and Tissue Kit (QIAGEN) columns (this sample is hereafter called as gut metagenome). Additionally, hemolymph from another 30 individuals of $D$. coccus adult females was obtained by dissection. Insect debris was separated by centrifugation in a Percoll (Sigma) gradient, and hemolymph cells were resuspended into $200 \mu \mathrm{l}$ of PBS and macerated using sterile plastic pestles (Eppendorf). DNA extraction and purification from this sample (hereafter called as hemolymph metagenome) was performed with DNeasy Blood and Tissue Kit (QIAGEN) following manufacturer's instructions.

\section{DNA Sequencing}

For gut metagenome DNA Illumina sequencing libraries were prepared using a fragment size of 400 bases and sequenced 


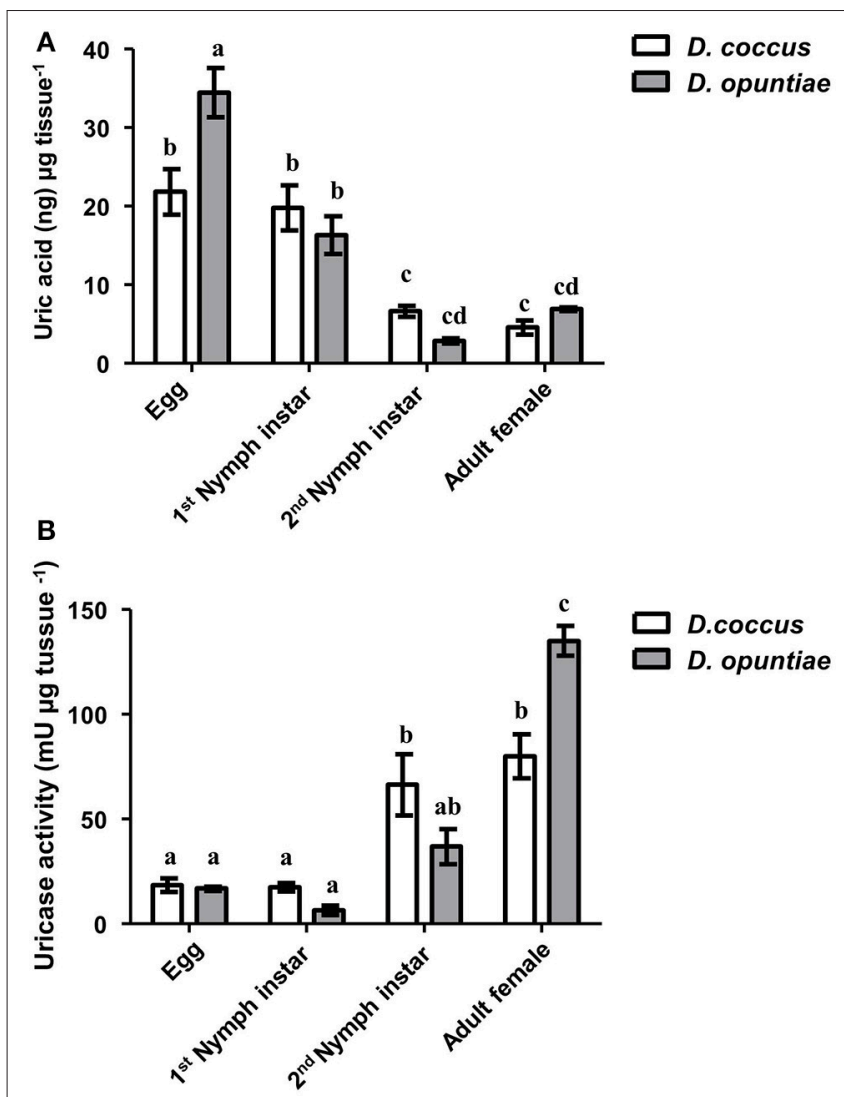

FIGURE 4 | Uric acid and uricase activity during different life stages of D. coccus and $\boldsymbol{D}$. opuntiae. (A) Uric acid content in ng per microgram tissue (Two way-ANOVA $P=0.1978 ; F=1.73$ d.f. 1). (B) Uricase activity in milli-Units per microgram tissue (Two way-ANOVA $P=0.5585 F=0.3496$ d.f. 1). Values are shown as means \pm SE of five independent experiments. Mean values with different letters are significantly different (Tuckey-HDS test $P<0.01$ ).

by Illumina HiSeq2000 platform using a configuration of 200 cycles to obtain pair-end reads of 100 base length. Both library preparation and sequencing were performed at Macrogen Inc. (Korea). The sample yielded a total of 58,146,564 reads. Additionally, DNA from hemolymph metagenome was sequenced using the 454 GS-FLX platform yielding 811,305 single reads.

\section{Metagenomic Fungal Ribosomal Gene In silico Reconstruction and Characterization}

Ribosomal genes from all metagenomic reads were obtained using Parallel-meta 2.4 (Su et al., 2014) algorithm. Eukaryotic ribosomal sequences were recovered using -E option against the SILVA database within an $e$-value of $1 \times 10^{-10}$ cutoff. Fungal $18 \mathrm{~S}$ rRNA sequences were retrieved from parsing Parallel-meta result tables. Fungal hits were visualized in Krona graphs (Ondov et al., 2011). 18S rRNA gene sequences were recovered from long reads of the hemolymph metagenome (>200 nt), compared to taxonomically related sequences from NCBI using BLASTn 2.2.30+ (Camacho et al., 2009) and used for maximum likelihood phylogenetic analysis. MODELTEST 3.06 was used to select appropriate models of sequence evolution by the AIC model. Model TrN was the best model $(\mathrm{A}=0.25409 ; \mathrm{C}=0.14918 ; \mathrm{G}$ $=0.20597 ; \mathrm{T}=0.39076)$. The ribosomal sequence retrieved was deposited in the GenBank database under the accession number KT351777.

\section{Gene Annotation and Purine Pathway Reconstruction}

To eliminate bacterial sequences, all metagenomic reads were mapped to Wolbachia $w \mathrm{DacA}$ and $w \mathrm{DacB}$ genomes previously obtained from D. coccus metagenome (Ramírez-Puebla et al., 2015) using Bowtie2 2.2.4 (Langmead and Salzberg, 2012). Un-mapped reads were retrieved by Samtools 1.2 ( $\mathrm{Li}$ et al., 2009). High-quality shotgun unmapped reads longer than 100 nucleotides were used directly for gene prediction and annotation. Gene prediction was performed using FragGeneScan 1.20 (Rho et al., 2010) with -w 0 -p 16 -t illumina_5 (gut, DCoax and DCperu metagenomes) and -t 454_5 (hemolymphmetagenome) parameters. Metabolic annotation was obtained from all putative coding gene predicted using GhostKoala tool from KEGG (Kanehisa et al., 2015). Fungal annotation was obtained by parsing the annotation result table using KEGGREST Bioconductor library (http://bioconductor.org/packages/release/ bioc/html/KEGGREST.html). A metabolic pathway of uric acid catabolism was constructed using KEEG Mapper-Search \& color Pathway tool (http://www.genome.jp/kegg/tool/map_pathway2. html) from fungal annotation results. All metagenomics reads from gut and hemolymph metagenomes were deposited in GenBank under SRA accession study SRP074499.

Additionally, to extend our metagenomic results we analyzed the two available Dactylopius metagenomes from the whole body (here after called DCoax and DCperu metagenome) deposited in GenBank under BioProject PRJNA244295 (Campana et al., 2015). For this, we performed a fungal ribosomal gene in silico reconstruction and the annotation of fungal reads related to uric acid catabolism as was described above.

\section{Phylogenetic Analysis}

Nucleotide sequences were compared against non-redundant GeneBank library by BLASTn 2.2.30+ (Camacho et al., 2009) and taxonomically related sequences were collected from NCBI. Cultured fungi were identified by ITS and 26S rRNA phylogenies obtained by Maximum likelihood. MODELTEST 3.06 was used to select appropriate models of sequence evolution by the AIC model (Posada, 2008). GTR $+\mathrm{I}+\mathrm{G}(\alpha=1.772$ for gamma distribution; $A=0.25778 ; C=0.23041 ; G=0.22501 ; T=$ $0.28681)$ was the best model for the ITS gene, while GTR + I $(\alpha$ $=0.383$ for gamma distribution; $A=0.25061 ; C=0.20735 ; G=$ $0.29982 ; T=0.24222$ ) was the best model for $26 \mathrm{~S}$ rRNA gene. A p-distance among sequences was calculated using DNAdist algorithm from Phylip 3.6 software (Felsenstein, 1989). Limits for genus and species were established at 95 and 97\%, respectively. To compare the sequences and quantify the number of fungi operational taxonomical units (OTUs) related with Dactylopius spp., a cluster analysis was performed using MOTHUR (Schloss et al., 2009) and ribosomal sequences were clustered at $0.03 \%$ 

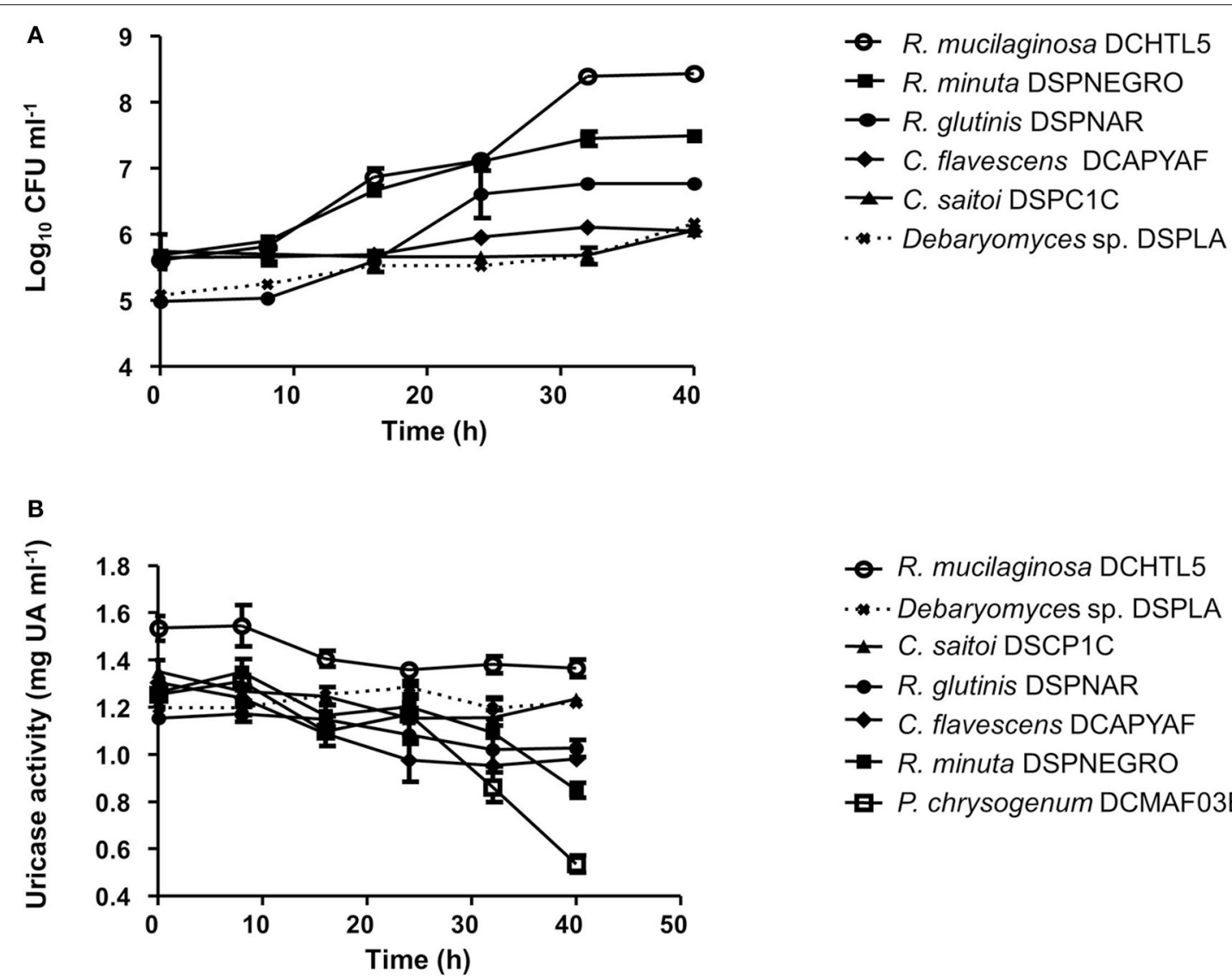

- R. mucilaginosa DCHTL5
* $\cdot$ Debaryomyces sp. DSPLA
- C. saitoi DSCP1C
$\rightarrow$ R. glutinis DSPNAR
- C. flavescens DCAPYAF
- R. minuta DSPNEGRO
— P. chrysogenum DCMAF03BB

FIGURE 5 | (A) Growth kinetics of uricolytic yeast associated with Dactylopius spp. using uric acid as sole nitrogen source. (B) Uric acid consumption kinetics of uricolytic yeast associated with Dactylopius spp. using uric acid as sole nitrogen source. Values are shown as means \pm SEM of three independent experiments.

distance. All sequences generated from ITS and 26S rRNA of cultured fungi were deposited in the GenBank database under the accessions numbers KM393247 to KM393282 and KT351741 to KT351776, respectively.

\section{Determination of Uric Acid and Uricase Activity in Dactylopius spp.}

Three guts from $D$. coccus and $D$. opuntiae in 1st instar nymph, 2nd instar nymph and adults, as well as eggs from both species, were dissected as mentioned above. Additionally male bodies were resuspended in $200 \mu$ l AmplexRed buffer solution. Also, $10 \mu \mathrm{l}$ of honeydew from $D$. coccus and D. opuntiae were resuspended in $100 \mu \mathrm{l}$ of the same buffer solution. UA and uricase activity were determined using the Amplex ${ }^{\circledR}$ Red Uric Acid/Uricase Assay Kit (Life Technologies Eugene, OR) following the manufacturer's instructions. Means of the UA content as well as uricase activity were compared using two-way ANOVA, and a Tukey-HSD post-hoc test was applied for pairwise comparisons between insects. Furthermore, to compare differences in UA content between honeydew and adult female guts a $t$ test was performed. All statistics test were performed using $\mathrm{R}$ version 3.1.

\section{Fungal Uricolytic Activity}

Individual guts and Malpighian tubules, from adults of $D$. opuntiae and D. coccus were placed separately in microtubes and macerated with sterile pestles in $200 \mu \mathrm{l}$ of sterile PBS. Serial 10 -fold dilutions from $10^{-1}$ to $10^{-3}$ were spread on duplicate plates of MU media $\left(\mathrm{K}_{2} \mathrm{HPO}_{4} 2.5 \mathrm{~g} \mathrm{l}^{-1} ; \mathrm{KH}_{2} \mathrm{PO}_{4} 5 \mathrm{~g}\right.$ $\mathrm{l}^{-1} ; \mathrm{MgSO}_{4} \bullet 7 \mathrm{H}_{2} \mathrm{O} 0.2 \mathrm{~g} \mathrm{l}^{-1} ; \mathrm{MnSO}_{4} 0.02 \mathrm{~g} \mathrm{l}^{-1} ; \mathrm{CaCl}_{2} 0.05 \mathrm{~g} \mathrm{l}^{-1}$; $\mathrm{FeSO}_{4} 0.05 \mathrm{~g} \mathrm{l}^{-1}$; uric acid (Sigma) $1.5 \mathrm{~g} \mathrm{l}^{-1}$; glucose $10 \mathrm{~g} \mathrm{l}^{-1}$ and agar $15 \mathrm{~g} \mathrm{l}^{-1}$ ). Plates were incubated at $28^{\circ} \mathrm{C}$ in $\mathrm{CO}_{2}$ atmosphere generated by BD GasPak EZ Pouch Systems ${ }^{\mathrm{TM}}$ for 7 days. Colonies with yeast-like macro and microscopic morphology surrounded with a clear halo (suggestive of uric acid utilization) were counted and colony forming units (CFU) per gut were obtained. All isolates were stored at $-70^{\circ} \mathrm{C}$. Additionally, uricolytic activity of 37 isolated fungi from Dactylopius spp. was tested measuring a degradation halo in YPU (Yeast extract $10 \mathrm{~g}$ $\mathrm{l}^{-1}$; Peptone $10 \mathrm{~g} \mathrm{l}^{-1}$, UA $7 \mathrm{~g}^{-1}$ ) medium. Enzyme activity was determined as described by Morales-Jiménez et al. (2013). To find out if UA was used by fungi isolates as sole nitrogen source, growth and UA consumption kinetics were performed. Microbial growth was measured quantifying the $\mathrm{CFU} \mathrm{m}{ }^{-1}$ for yeast and by weighing the final biomass for molds grown in liquid MU media. UA consumption was quantified by measuring the decrease in 
TABLE 3 | Uric acid consumed as sole nitrogen source by fungi isolated from Dactylopius.

\begin{tabular}{|c|c|c|c|}
\hline Isolate & $\begin{array}{l}\text { Uric acid consumed } \\
\qquad\left(\mu \mathrm{g} \mathrm{ml}^{-1}\right)\end{array}$ & $\begin{array}{c}\text { Sperman correlation } \\
\boldsymbol{R} \text {-value }\end{array}$ & $P$-value \\
\hline $\begin{array}{l}\text { Rhodotorula glutinis } \\
\text { DSPNAR }\end{array}$ & $127.6 \pm 42.54$ & -0.922 & 0.0045 \\
\hline $\begin{array}{l}\text { Cryptococcus saitoi } \\
\text { DSPC1C }\end{array}$ & $119.9 \pm 62.16$ & -0.725 & 0.0515 \\
\hline $\begin{array}{l}\text { Rhodotorula minuta } \\
\text { DSPNEGRO }\end{array}$ & $414.8 \pm 66.43$ & -0.897 & 0.0128 \\
\hline $\begin{array}{l}\text { Rhodotorula } \\
\text { mucilaginosa } \\
\text { DCHTL5 }\end{array}$ & $170.5 \pm 89.54$ & -0.867 & 0.0127 \\
\hline $\begin{array}{l}\text { Cryptococcus } \\
\text { flavescens } \\
\text { DCAPYAF }\end{array}$ & $323.5 \pm 37.34$ & -0.925 & 0.0041 \\
\hline $\begin{array}{l}\text { Debaryomyces sp. } \\
\text { DSPA }\end{array}$ & $0.0 \pm 0.0$ & 0.221 & 0.3372 \\
\hline $\begin{array}{l}\text { Penicillium sp. } \\
\text { DCM03BB }\end{array}$ & $717.9 \pm 27.05$ & -0.892 & 0.0085 \\
\hline
\end{tabular}

absorbance at $295 \mathrm{~nm}$. These results were compared against a standard curve of UA. A Sperman correlation was performed to assess a negative correlation and differences in UA consumption in relation to time.

\section{Antifungal Treatment}

A group of 15 first instar nymphs of $D$. opuntiae was fed on a prickly pear pad of Opuntia ficus-indica injected with $5 \mathrm{ml}$ of $20 \mu \mathrm{g} \mathrm{ml}^{-1}$ antifungal cocktail of Ketoconazol (Sigma), Anfotericine B (Sigma), and Fludioxonil (Sigma). Fleshy leaves were injected weekly for 4 weeks and then female insects were removed. O. ficus-indica leaves without antifungal were similarly infested and used as negative controls. After treatment, a pool of six individuals of each leaf was used to measure differences in dry weight, UA content and uricase activity. Five replicates of this experiment were performed. UA content, uricase activity and dry weight data were compared between controls and treatments using a $t$-test.

\section{Fluorescent In situ Hybridization (FISH)}

FISH was performed as previously described by Koga et al. (2009) with slight modifications. Ninety-day old D. coccus and D. opuntiae were collected. Malpighian tubules, as well as ovaries and embryos (25 from D. coccus and 20 from D. opuntiae) were dissected as described above. These organs were embedded in 3\% agarose and treated as described by Rosas-Pérez et al. (2014). The oligonucleotide probe used was Cy5-Cry851 (5'-TGATGCGA GTTTCTGCTATC-3'), which targets $26 \mathrm{~S}$ rRNA of Cryptococcus saitoi (designed for this work). After washing with PBS the samples were stained with $2.4 \mu \mathrm{g} \mathrm{ml}^{-1}$ of DAPI and mounted with citifluor antifade solution. To confirm probe specificity, control experiments were performed with no probe and RNAse digestion. The samples were observed under an Olympus FV100 Multi-photonic confocal microscopy. Images were processed using FIJI 2.0.0 software (Schindelin et al., 2012).

\section{RESULTS}

\section{Culture-Dependent and Culture-Independent Analyses of Fungal Communities}

A total of 37 fungal isolates were cultured from D. coccus, D. opuntiae, and D. confusus. Isolates were obtained from guts, whole bodies and ovary samples (Table 2). Nucleotide sequences of 26S rRNA genes and ITS regions from different morphotypes corresponded to 14 OTUs. 26S rRNA and ITS phylogenetic analyses showed sequences belonging to Ascomycota and Basidiomycota with Rhodotorula, Cryptococcus and Penicillium as the most frequent genera (Figure 1; Supplementary Figure 1). Fungal species like Rhodotorula mucilaginosa and Cryptococcus saitoi were present in the three Dactylopius species sampled, whereas Trametes polizona was present in D. coccus and D. opuntiae (Table 2). Three filamentous fungi had an ITS sequence identity of 77.6 and $88.9 \%$ to Stereum sp. and Periconia sp. (DCHG and DCHM) respectively (Figure 1; Table 2). In $26 \mathrm{~S}$ rRNA phylogenies, the closest related sequences of these novel fungi were Phlebiopsis flavidoalba (DCHBPI) with $97.8 \%$ identity and Periconia macrospinosa (DCHG and DCHM) with $93.74 \%$ identity (Table 2, Supplementary Figure 1). Likewise, from $D$. coccus we could isolate the mold Penicillium from 1st instar nymphs $(n=3)$ and males $(n=5)$ but not from adult females (Figure 1; Table 2; Supplementary Figure 1).

From the metagenomic data of the hemolymph and gut metagenomes, fungal $18 \mathrm{~S}$ rRNA gene sequences were detected. Hemolymph metagenome sequences were assigned particularly to Sebacina vermifera, Bullera ninhbinhensis (Basidiomycetes), and Candida lignicola (Ascomycetes; Figure 2; Supplementary Data Sheet 1). In congruence, a phylogenetic reconstruction of $18 \mathrm{~S}$ rRNA ( $\sim 200 \mathrm{nt}$ ) from this sample showed the presence of Pichia anomala (100\% identity) in Dactylopius hemolymph (Supplementary Figure 2). In gut metagenome, we found sequences related to Basidiomycota, particularly to the Sebacinaceae family (Craterocolla sp. and Sebacina sp.) and Ustilaginaceae family (Rhodosporidium sp.), as well as sequences related to Chytridiomycota and Glomeromycota phyla (Figure 2; Supplementary Data Sheet 1). Remarkably, most of the fungal sequences obtained by the metagenomic analysis were associated with uncultured and unclassified fungi (Figure 2; Supplementary Data Sheet 1). Analysis of DCoax metagenome showed sequences related to Basidiomycota (Agaricus bisporus and Thanatephorus cucumeris), Ascomycota (Blastobostrys adeninivorans and Candida sp.), Glomeromycota and some unclassified fungi (Figure 2; Supplementary Data Sheet 1). From DCperu metagenome the only fungal species detected was Candida sp.

\section{Metagenomic Annotation of Fungal Genes Involved in Uric Acid Catabolism}

A total of 518,258 open reading frames (ORFs) were predicted from the hemolymph metagenome and 20,136,058 ORFs from the gut metagenome. From those, only 2,874 and 66,502 corresponded to fungal ORFs, respectively. Metabolic annotation 


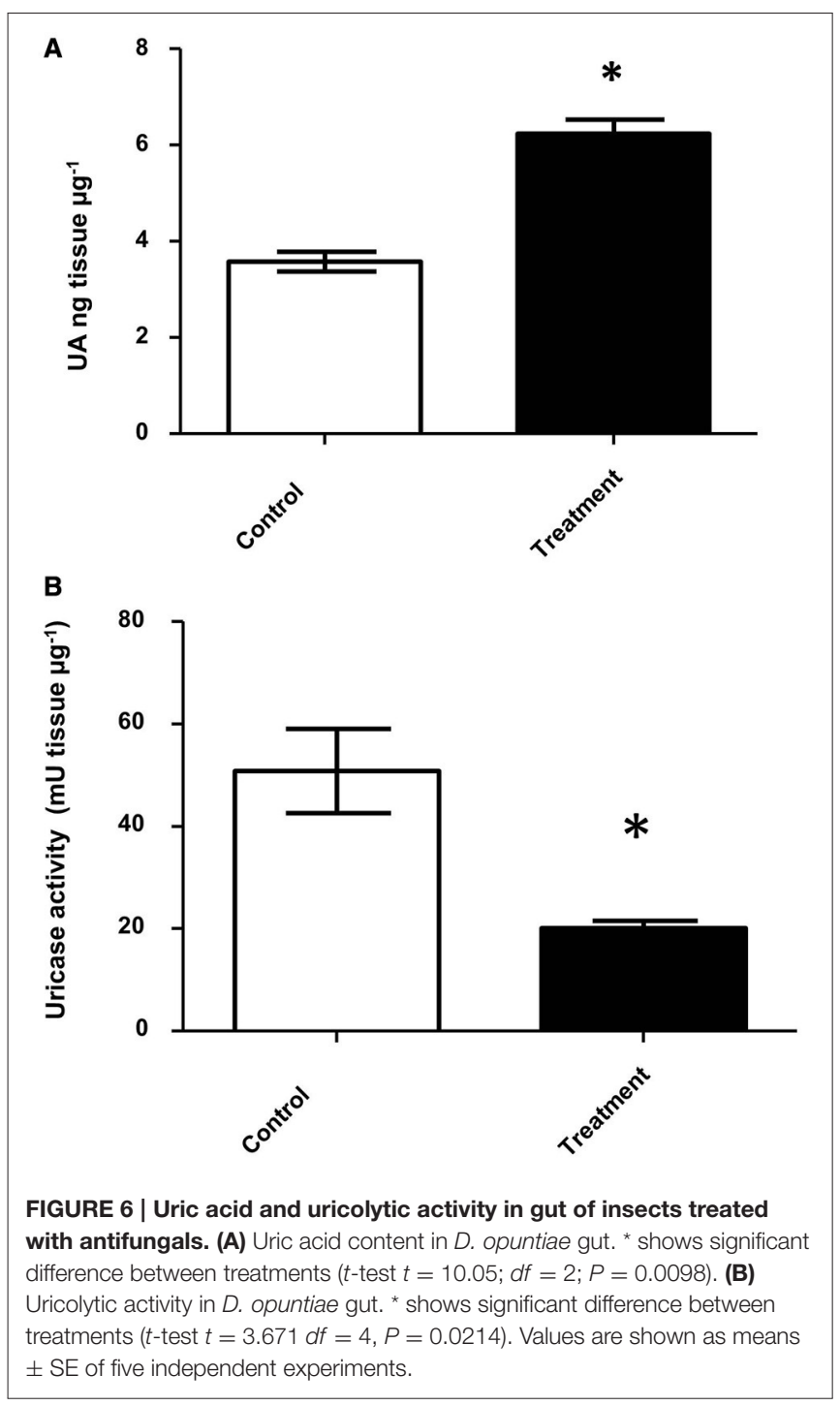

of these fungal ORFs revealed genes related to UA metabolism (Figure 3). Particularly, we detected the presence of 20 and 85 fungal genes involved in UA catabolism from hemolymph and gut metagenome, respectively (Supplementary Table 1). All coding genes for xanthine degradation to urea were present in gut metagenome whereas in hemolymph metagenome we did not find any allantoinase fungal genes (Figure 3). From DCoax metagenome a total of $8,911,722$ ORFs were estimated and $8,901,672$ were properly annotated by Ghost-KOALA, from which 262,623 corresponded to fungal sequences. We found 128 putative genes involved in uric acid catabolism in this metagenome (Supplementary Table 2). From the DCperu metagenome, 8,619,769 ORFs were predicted; 8,611,041 had a functional annotation and 226,810 belonged to fungal sequences. A total of 101 putative genes of uric acid catabolism were present in this sample (Supplementary Table 3). As in gut metagenome, all genes for xanthine catabolism to urea were found in DCoax and DCperu metagenomes (Supplementary Figure 3).

\section{UA and Uricase Activity in Dactylopius spp. Guts}

UA and uricase activities were detected in D. opuntiae and $D$. coccus extracts where the changes in UA concentration depended on the insect developmental stage (Figure 4A). The highest amount of UA was present in eggs of both species

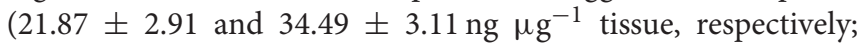
Supplementary Table 4) whereas the lowest was in D. coccus adult male, $D$. coccus female and in D. opuntiae 2nd instar nymph (4.49

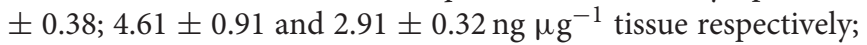
Supplementary Table 4).

Post-hoc comparison using Tukey-HSD test showed significant differences in UA content among eggs, 1st instar nymph, and adults in both species, although no significant difference was seen between 2nd nymph instar and adult (Figure 4A).

Urate oxidase or uricase (EC 1.7.3.3 or UOX) is a homotetramer that catalyzes the conversion of UA and molecular oxygen to 5-hydroxyurate and hydrogen peroxide (Gabison et al., 2008). In our results, this enzyme showed high activity in adult females of both Dactylopius species $\left(80 \mathrm{mU} \mathrm{gg}^{-1}\right.$ tissue for

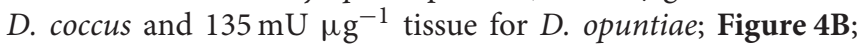
Supplementary Table 4). Post-hoc test showed significant differences in uricolytic activity in all stages (Figure 4B). The content of uric acid in adult's honeydew in both scale species was low, $0.18 \pm 0.05$ and $0.58 \pm 0.05 \mathrm{ng} \mu \mathrm{l}^{-1}$ in $D$. coccus and $D$. opuntiae, respectively. A $t$-test showed a significant difference between UA content in honey dew and adults gut $(D$. coccus $P=0.0006 ; t=4.856 ; d f=8 ; D$. opuntiae $P<0.0001 ; t=26.85$; $d f=8$ ), moreover no urate oxidase activity was detected in these samples. This supports the idea that UA is metabolized inside the insect.

\section{Uricolytic Fungi Associated with Dactylopius}

The number of uricolytic yeast CFUs in MU from D. opuntiae gut was estimated in $4.1 \times 10^{2} \pm 0.74 \times 10^{2} \mathrm{CFU}_{\text {gut }^{-1}}$. The isolates C. flavescens DCPYAF01, R. mucilaginosa DCHTL5, $R$. minuta DSPNEGRO, R. glutinis DSPNAR, C. saitoi DSPCUB, and the mold Penicillium sp. DCFM03BB (Figure 1; Table 2), were capable of growth and consumption of UA as sole nitrogen source (Figures 5A,B; Table 3). The maximum consumption rates were with Penicillium sp. DCMAF03BB and R. minuta DSPNEGRO $(717.9 \pm 27.05$ and $414.8 \pm 66.43 \mu$ g of UA respectively; Table 3$)$. Debaryomyces sp. DSPA showed no significant growth and there was no evidence for UA uptake by this strain (Figures 5A,B; Table 3).

\section{Antifungal Effects on UA Concentration and Uricase Activity in D. opuntiae}

After four weeks with antifungal treatment $D$. opuntiae weight was significantly lower in comparison to the controls $(2.50 \pm$ 0.15 and $0.58 \pm 0.12 \mathrm{mg}$ respectively; $t=6.954 ; d f=4$; $P=0.0201$; Supplementary Figure 4). Uric acid concentration was significantly higher in fungicide treated insects vs. controls $\left(6.25 \pm 0.28\right.$ and $3.58 \pm 0.21 \mathrm{UA} \mathrm{ng}_{\mu \mathrm{g}^{-1}}$ tissue $^{1}$ respectively; 
A

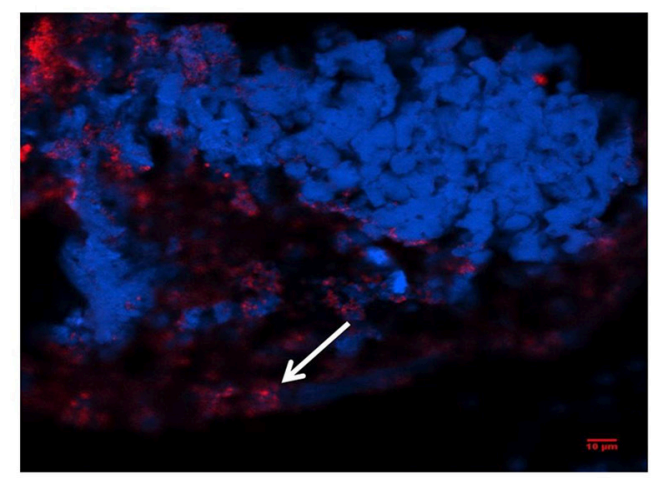

Dactylopius opuntiae embryo

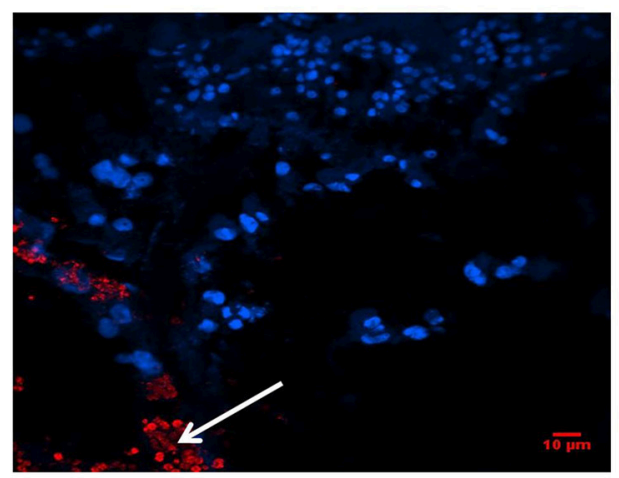

Negative controls

B

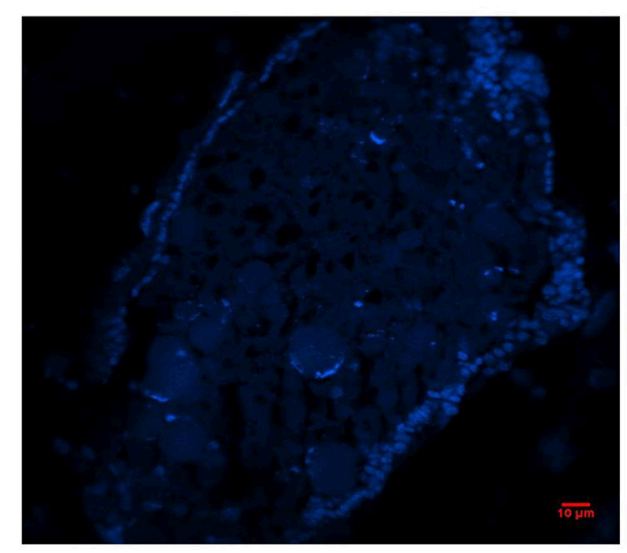

FIGURE 7 | Localization of Cryptococcus saitoi inside Dactylopius. In the fluorescence in situ hybridization (FISH) images, blue and red signals indicate insect nuclear DNA and fungi respectively. (A) Left D. coccus embryo; right D. opuntiae embryo. (B) No-probe controls; Left $D$. coccus embryo; right $D$. opuntiae embryo. White arrows show C. saitoi signal.

Figure 6A). Additionally, uricase activity was significant lower in antifungal treatments than in controls $(20.20 \pm 1.35$ and $50.91 \pm$ $8.26 \mathrm{mU}$ tissue $\mu \mathrm{g}^{-1}$, respectively; Figure 6B).

\section{Cryptococcus saitoi Localization in Dactylopius}

Fluorescent in situ hybridization of D. coccus and D. opuntiae showed the presence of $C$. saitoi in embryos of both species (Figures 7A,B). Of 25 embryos of D. coccus and 20 of D. opuntiae, $17(68 \%)$ and $14(70 \%)$ contained the fluorescent signal. FISH analysis showed that $C$. saito $i$ fungi were on the egg surface. Additionally, C. saito $i$ was observed by FISH in a distal part of the Malpighian tubules in D. coccus (Supplementary Figure 5).

\section{DISCUSSION}

A comprehensive study of the fungal community associated with Dactylopius is presented here, where different species in four fungal phyla were found by culture and culture-independent analyses. C. saitoi and R. mucilaginosa were found in most female samples (Figure 2) while Penicillum was the only fungus found in males (Figure 1; Table 2; Supplementary Figure 1). Penicillium has been associated with other insects such as bees, beetles, termites, and as well as in Triatoma sp. guts (Batra et al., 1973; Lage-Moraes et al., 2001; Pérez et al., 2003). The cultured fungi obtained belonging to Rhodotorula, Cryptococcus, Trametes, Penicillium, and Debaryomyces (Figure 1; Supplementary Figure 1) were previously found in other phytophagous insects (Jones et al., 1999; Guevara et al., 2000; Suh et al., 2001; Ganter, 2006; Kobayashi et al., 2007). Particularly in the scale insect Saissetia oleae, Cryptococcus, and Rhodotorula yeasts were isolated from the gut and reproductive organs (Zacchi and Vaughan-Martini, 2003). Similarly, in the reproductive tissues and guts from D. coccus and D. opuntiae, we found Cryptococcus and Rhodotorula by a culture dependent approach and by FISH (Figure 7; Table 2; Supplementary Figure 5). In culture we also found $P$. flavidoalba (DCHBPI), Periconia macrospinosa (DCHG and DCHM) and Irpex lacteus (DCALI) which, to our knowledge, have not been previously isolated from insect's inner 
tissues. In this work ITS and 26S rDNA markers were used for culture-fungi identification and in few cases genus or species assignment differed depending on the marker used (Table 2), indicating that single gene phylogenetic stories are not fully reliable and a better sample of the genome is needed in novel groups.

Most of the fungal ribosomal sequences from the female metagenomic analyses belonged to uncultured or nonclassified fungi. With $\sim 100-300$ base pair reads an accurate classification may be difficult. Additionally, fungal sequences are underrepresented in metagenomics because of limited information in databases used for the analysis and problems in fungal DNA extraction from different samples (Lindahl and Kuske, 2013; Escobar-Zepeda et al., 2015). However, members of Chytridiomycota and Glomeromycota phyla (Figure 2; Supplementary Data Sheet 1) were recovered form D. coccus metagenomes. There are reports of entomopathogenic Chytridiomycota associated with elm bark beetles, blackflies, and aquatic dipteran larvae (Humber et al., 1990; Powell, 1993), but not in scale insects. Glomeromycota is a phylum of asexual fungi from arbuscular mycorrhiza of plants, they are obligate endosymbionts and cannot be grown in pure culture in the absence of their plant host (Hempel et al., 2007; Gianinazzi-Pearson and Van Tuinen, 2012). Interestingly, there are no reports of this fungal phylum associated with insects, although some sequences related to mycorrhizal fungi have been found in other habitats like the human oral cavity (Ghannoum et al., 2010; Cui et al., 2013). In Dactylopius we found sequences of Glomeromycota in gut and whole body (Supplementary Data Sheet 1). It is tempting to speculate that its presence could mediate a close interaction between insects and their host plant. This is the first report of Glomeromycota in insects.

Sequences of Candida, which we did not recover in cultures (Figure 1; Table 2; Supplementary Figure 1), were found in all female Dactylopius metagenomes (Supplementary Data Sheet 1; Supplementary Figure 2). Species of Candida have been isolated from insect guts as well as in mycetocytes of other hemipterans (Gibson and Hunter, 2005; Vega and Blackwell, 2005; Suh et al., 2008; Hughes et al., 2011).

Additionally, we report here the presence of uricolityc fungi associated with Dactylopius spp. Nitrogen content in O. ficusindica cladodes is around $0.5-1 \%$ of wet weight (Stintzing and Carle, 2005). Meanwhile in Dactylopius this element constitutes about $32 \%$ of wet weight (Gómez-Hernández, 2006). This means that Dactylopius has to accumulate 30 times the nitrogen present in the cactus. It is known that $\mathrm{N}_{2}$ recycling by UA catabolism provides nitrogen to plant feeding insects (Potrikus and Breznak, 1981; Sasaki et al., 1996; Morales-Jiménez et al., 2013; PatiñoNavarrete et al., 2014). However, bacteria are often mentioned as major recyclers in these scenarios and only in the brown plant hopper (Nilaparvata luggens) it has been shown that many unicellular fungi symbionts called yeast-like symbionts (YLS) are involved in insect UA metabolism (Sasaki et al., 1996). Plant hoppers produce and store UA when fed nitrogen-rich diets, but when nitrogen is limited their YLS mobilize the stored UA using the enzyme uricase (EC:1.7.3.3). This process may turn UA into amino acids for insects. Yeast isolates from $D$. coccus and D. opuntiae females as well as the mold Penicillium from $D$. coccus males were capable of metabolizing UA as sole nitrogen source (Figures 5A,B; Supplementary Table 4) There are reports for UA catabolism in Cryptococcus and Penicillium (Allam and Elzainy, 1969; Lee et al., 2013) but to our knowledge there are no reports for uricolytic Rhodotorula (Middelhoven et al., 1985). In termites (Reticulotermes flavipes) and in bark beetles (Dendroctonus valens and Dendroctonus rhizophagus) uricolytic microorganisms have been isolated from their guts (Potrikus and Breznak, 1980; Morales-Jiménez et al., 2013), in agreement most of the Dactylopius uricolytic fungi come from the alimentary canal (Figures 5A,B; Table 2). FISH analysis showed the presence of Cryptoccocus (uricolytic yeast) in Malpighian tubules of D. coccus (Supplementary Figure 5). Additionally, metagenomic analysis of guts and hemolymph of D. coccus and whole body of other $D$. coccus revealed the presence of fungal genes involved in UA catabolism (Figure 3; Supplementary Figure 3; Supplementary Tables 2, 3). Uricase catalyzes the first step in UA catabolism (Gabison et al., 2008). Even though putative genes for uricase were present in all metagenomes analyzed, there was only one ORF codifying for this enzyme in hemolymph metagenome; meanwhile in the gut metagenome 18 of these genes were found (Supplementary Table 2). This supports the idea that UA could be metabolized by fungi in Dactylopius gut, as in other insects, rather than directly in hemolymph. Besides, putative fungal genes for allantoinase, allantoicases, and ureases were also found. This suggests that UA can be catabolized to urea and ammonia by fungi (Figure 3; Supplementary Figure 3). It is known that in silkworm Bombix mori and in the larvae of the bruchid beetle Caryedes brasiliensis urea can be incorporated into insect proteins as an alternative nitrogen source (Hirayama et al., 1999). In Dactylopius uric acid could be metabolized into urea by their associated fungi and then used as nitrogen by its insect host.

Different levels of UA during life stages have been detected in other Hemiptera. Particularly in Parastrachia japonensis, UA is higher before copulation and during ovarian development and lower in nymph stages (Kashima et al., 2006). In contrast, in Dactylopius we found that UA is higher in nymphs as compared to adults (Figure 4A; Supplementary Table 4). Uricase activity was detected in Dactylopius guts in all life stages, in contrast this enzyme is absent in the majority of insects (Pant, 1988). However, some insect symbionts present uricase activity (Potrikus and Breznak, 1981; Hongoh and Ishikawa, 2000). In the shield bug $P$. japonensis treatment with antibiotics produce a reduction in uricolytic activity and in amino acid concentration in hemolymph (Kashima et al., 2006). In Dactylopius, antifungal treatment showed a similar significant decrease of uricase activity (Figure 6B), additionally UA concentration was higher in those insects treated (Figure 6A). As mentioned, the metagenomic approach revealed fungal uricase genes (Figure 3; Supplementary Figure 3; Supplementary Tables 1-3), that in addition to the experimental evidence of UA accumulation and lower uricolytic activity in antifungal treated insects (Figures 6A,B), suggest that the uricase detected in the enzymatic assay on Dactylopius (Figure 4B; Table 3) may come from their 
associated fungi. In conclusion fungi associated to Dactylopius could recycle nitrogen in order to supply deficiencies in their diet.

\section{AUTHOR CONTRIBUTIONS}

The experiments were conceived and designed by AV, AS, MR, and EM, and were conducted and analyzed by AV and AS. All authors contributed to interpreting the results and writing the article.

\section{FUNDING}

This work was supported by Consejo Nacional de Ciencia y Tecnologia grant 154453 and graduate student (AVPL) grant 331625.

\section{ACKNOWLEDGMENTS}

To CONACyT Basic Science grant 154453. AVPL is a doctoral student from Programa de Doctorado en Ciencias Biomédicas,

\section{REFERENCES}

Allam, A., and Elzainy, T. (1969). Degradation of xanthine by Penicillium chrysogenum. J. Gen. Microbiol. 56, 293-300.

Batra, L. R., Batra, S. W. T., and Bohart, G. E. (1973). The mycoflora of domesticated and wild bees (Apoidea). Mycopathol. Mycol. Appl. 49, 13-44.

Ben-Dov, Y., and Marotta, S. (2001). Taxonomy and family placement of Coccus bassi Targioni Tozzetti, 1867 (Hemiptera: Coccoidea). Phytoparasitica 29, 169-170. doi: 10.1007/BF02983961

Brand, J. M., Bracke, J., Briton, L., Markovetz, A., and Barras, S. (1976). Bark beetle pheromones: production of verbenone by a mycangial fungus of Dendroctonus frontalis. J. Chem. Ecol. 2, 195-199.

Buchner, P. (1965). Endosymbiosis of Animals with Plant Microorganisms. New York, NY: John Wiley \& Sons, Inc.

Camacho, C., Coulouris, G., Avagyan, V., Ma, N., Papadopoulos, J., Bealer, K., et al. (2009). BLAST+: architecture and applications. BMC Bioinformatics 10:421. doi: 10.1186/1471-2105-10-421

Campana, M. G., Robles García, N. M., and Tuross, N. (2015). America’s red gold: multiple lineages of cultivated cochineal in Mexico. Ecol. Evol. 5, 607-617. doi: 10.1002/ece3.1398

Chávez-Moreno, C. K., Tecante, A., and Casas, A. (2009). The Opuntia (Cactaceae) and Dactylopius (Hemiptera: Dactylopiidae) in Mexico: a historical perspective of use, interaction and distribution. Biodivers. Conserv. 18, 3337-3355. doi: 10.1007/s10531-009-9647-x

Chen, C., Cheng, L., and Hou, R. (1981). Studies on the intracellular yeast-like symbiote in the brown planthopper, Nilaparvata lugens Stal. Zeitschrift Angew $92,440-449$.

Cui, L., Morris, A., and Ghedin, E. (2013). The human mycobiome in health and disease. Genome Med. 5, 63. doi: 10.1186/gm467

da Silva Santos, A. C., Oliveira, R. L. S., da Costa, A. F., Tiago, P. V., and de Oliveira, N. T. (2015). Controlling Dactylopius opuntiae with Fusarium incarnatumequiseti species complex and extracts of Ricinus communis and Poincianella pyramidalis. J. Pest Sci. 89, 539-547. doi: 10.1007/s10340-015-0689-4

Deveoglu, O., Karadag, R., and Yurdun, T. (2011). Qualitative HPLC determination of main anthraquinone and lake pigment contents from Dactylopius coccus dye insect. Chem. Nat. Comp. 47, 103-104. doi: $10.1007 /$ s10600-011-9842-3

Douglas, A. E. (2009). The microbial dimension in insect nutritional ecology. Funct. Ecol. 23, 38-47. doi: 10.1111/j.1365-2435.2008.01442.x
Universidad Nacional Autónoma de México (UNAM) and received the 331625 fellowship from Consejo Nacional de Ciencia y Tecnología (CONACyT). To Michael Dunn, Angela E. Douglas and Meztlli Gaytán for discussions and valuable comments on the manuscript. To J. Martínez-Romero for technical help. To Héctor González-Hernández for his help to identify the wild Dactylopius specimens. To Jesús A. ChávezVargas and Campo Carmín Company for D. coccus provided. To Alejandra Escobar-Zepeda, Jérôme Verleyen, Leticia Vega, Karel Estrada, and Veronica Jiménez-Jacinto for their help in bioinformatics support. All bioinformatics were performed in USMB-UNAM servers. We thank the "Unidad de Secuenciación Masiva y Bioinformática" of the "Laboratorio Nacional de Apoyo Tecnológico a las Ciencias Genómicas," CONACyT \#260481, at the Instituto de Biotecnología/UNAM.

\section{SUPPLEMENTARY MATERIAL}

The Supplementary Material for this article can be found online at: http://journal.frontiersin.org/article/10.3389/fmicb. 2016.00954

Ebbert, M., A, Marlowe, J. L., and Burkholder, J. J. (2003). Protozoan and intracellular fungal gut endosymbionts in Drosophila: prevalence and fitness effects of single and dual infections. J. Invertebr. Pathol. 83, 37-45. doi: 10.1016/S0022-2011(03)00033-8

Escobar-Zepeda, A., Vera-Ponce de León, A., and Sanchez-Flores, A. (2015). The road to metagenomics: from microbiology to DNA sequencing technologies and bioinformatics. Front. Genet. 6:348. doi: 10.3389/fgene.2015.00348

Felsenstein, J. (1989). Phylip: phylogeny inference package (version 3.2). Cladistics 5, 164-166.

Gabison, L., Prangé, T., Colloc'h, N., El Hajji, M., Castro, B., and Chiadmi, M. (2008). Structural analysis of urate oxidase in complex with its natural substrate inhibited by cyanide: mechanistic implications. BMC Struct. Biol. 8:32. doi: 10.1186/1472-6807-8-32

Ganter, P. (2006). "Yeast and invertebrate associations," in Biodiversity and ecophysiology of yeasts The Yeast Handbook, eds G. Péter and C. Rosa (Berlin/Heidelberg: Springer-Verlag), 303-370.

Ghannoum, M. A, Jurevic, R. J., Mukherjee, P. K., Cui, F., Sikaroodi, M., Naqvi, A., et al. (2010). Characterization of the oral fungal microbiome (mycobiome) in healthy individuals. PLoS Pathog. 6:e1000713. doi: 10.1371/journal.ppat.1000713

Gianinazzi-Pearson, V., and Van Tuinen, D. (2012). "Exploring the genome of glomeromycotan fungi," in Fungal Associations, ed B. Hock (Heidelberg: Springer-Verlag), 1-21.

Gibson, C. M., and Hunter, M. S. (2005). Reconsideration of the role of yeasts associated with Chrysoperla green lacewings. Biol. Control 32, 57-64. doi: 10.1016/j.biocontrol.2004.06.006

Gibson, C. M., and Hunter, M. S. (2009). Negative fitness consequences and transmission dynamics of a heritable fungal symbiont of a parasitic wasp. Appl. Environ. Microbiol. 75, 3115-3119. doi: 10.1128/AEM.00361-09

Gibson, C. M., and Hunter, M. S. (2010). Extraordinarily widespread and fantastically complex: comparative biology of endosymbiotic bacterial and fungal mutualists of insects. Ecol. Lett. 13, 223-234. doi: 10.1111/j.14610248.2009.01416.x

Gómez-Hernández, B. (2006). Extracción y Acetilación de los Componentes de la Grana Cochinilla (Dactylopius coccus Costa), Master dissertation, Universidad Autonoma del Estado de Hídalgo, Mexico. Available online at: http://repository.uaeh.edu.mx/bitstream/bitstream/handle/123456789/11155/ Extracci\%c3\%b3n\%20y\%20acetilaci\%c3\%b3n\%20de\%20los\%20componentes\% $20 \mathrm{de} \% 20$ la $\% 20$ grana $\% 20$ cochinilla $\% 20 \% 28$ Dactylopius $\% 20$ coccus $\% 20$ COSTA 29.pdf? sequence $=1$ \&isAllowed $=y$ 
Guevara, R., Rayner, A. D. M., and Reynolds, S. E. (2000). Effects of fungivory by two specialist ciid beetles (Octotemnus glabriculus and Cis boleti) on the reproductive fitness of their host fungus, Coriolus versicolor. New Phytol. 145, 137-144. doi: 10.1046/j.1469-8137.2000.00552.x

Hempel, S., Renker, C., and Buscot, F. (2007). Differences in the species composition of arbuscular mycorrhizal fungi in spore, root and soil communities in a grassland ecosystem. Environ. Microbiol. 9, 1930-1938. doi: 10.1111/j.1462-2920.2007.01309.x

Hirayama, C., Sugimura, M., and Shinbo, H. (1999). Recycling of urea associated with the host plant urease in the silkworm larvae, Bombyx mori. J. Insect Physiol. $45,15-20$.

Hoffman, C. S., and Winston, F. (1987). A ten-minute DNA preparation from yeast efficiently releases autonomous plasmids for transformation of Escherichia coli. Gene 57, 267-272.

Hongoh, Y., and Ishikawa, H. (2000). Evolutionary studies on uricases of fungal endosymbionts of aphids and planthoppers. J. Mol. Evol. 51, 265-277. doi: 10.1007/s002390010088

Hughes, G. L., Allsopp, P. G., Webb, R. I., Yamada, R., Iturbe-Ormaetxe, I., Brumbley, S. M., et al. (2011). Identification of yeast associated with the planthopper, Perkinsiella saccharicida: potential applications for Fiji leaf gall control. Curr. Microbiol. 63, 392-401. doi: 10.1007/s00284-011-9990-5

Humber, R. A., Samson, R. A., Evans, H. C., and Latge, J.-P. (1990). Atlas of entomopathogenic fungi. Mycologia 82, 148.

Jones, K. G., Dowd, P. F., and Blackwell, M. (1999). Polyphyletic origins of yeastlike endocytobionts from anobiid and cerambycid beetles. Mycol. Res. 103, 542-546.

Kanehisa, M., Sato, Y., and Morishima, K. (2015). BlastKOALA and GhostKOALA: KEGG tools for functional characterization of genome and metagenome sequences. J. Mol. Biol. 4, 726-731. doi: 10.1016/j.jmb.2015.11.006

Kashima, T., Nakamura, T., and Tojo, S. (2006). Uric acid recycling in the shield bug, Parastrachia japonensis (Hemiptera: Parastrachiidae), during diapause. J. Insect Physiol. 52, 816-825. doi: 10.1016/j.jinsphys.2006.05.003

Klepzig, K., and Six, D. (2004). Bark beetle-fungal symbiosis: context dependency in complex associations. Symbiosis 37, 189-205. Available online at: http:// www.srs.fs.usda.gov/pubs/ja/ja_klepzig003.pdf

Kobayashi, C., Fukasawa, Y., Hirose, D., and Kato, M. (2007). Contribution of symbiotic mycangial fungi to larval nutrition of a leaf-rolling weevil. Evol. Ecol. 22, 711-722. doi: 10.1007/s10682-007-9196-2

Koga, R., Tsuchida, T., and Fukatsu, T. (2009). Quenching autofluorescence of insect tissues for in situ detection of endosymbionts. Appl. Entomol. Zool. 44, 281-291. doi: 10.1303/aez.2009.281

Lage-Moraes, A. M., Reis-de-Figueiredo, A., Vieira-Junqueira, A. C., Lara-daCosta, G., Aguiar, R. K., and Cunha-de-Oliveira, P. (2001). Fungal flora of the digestive tract of Panstrongylus megistus (Reduviidae) used for experimental xenodiagnosis of Trypanosoma (Schizotripanum) cruzi Chagas, 1909. Rev. Iberoam. Micol. 18, 79-82.

Langmead, B., and Salzberg, S. L. (2012). Fast gapped-read alignment with Bowtie 2. Nat. Methods 9, 357-359. doi: 10.1038/nmeth.1923

Lee, I. R., Yang, L., Sebetso, G., Allen, R., Doan, T. H. N., Blundell, R., et al. (2013). Characterization of the complete uric acid degradation pathway in the fungal pathogen Cryptococcus neoformans. PLoS ONE 8:e64292. doi: 10.1371/journal.pone.0064292

Li, H., Handsaker, B., Wysoker, A., Fennell, T., Ruan, J., Homer, N., et al. (2009). The sequence alignment/map format and SAMtools. Bioinformatics 25, 2078-2079. doi: 10.1093/bioinformatics/btp352

Lindahl, B. D., and Kuske, C. R. (2013). "Metagenomics for study of fungal ecology," in The Ecological Genomics of Fungi, ed F. Martin (Hoboken, NJ: John Wiley \& Sons, Inc.), 279-303.

Middelhoven, W. J., de Kievit, H., and Biesbroek, A. L. (1985). Yeast species utilizing uric acid, adenine, $\mathrm{n}$-alkylamines or diamines as sole source of carbon and energy. Antonie Van Leeuwenhoek 51, 289-301.

Morales-Jiménez, J., Vera-Ponce de León, A., García-Domínguez, A., MartínezRomero, E., Zúñiga, G., and Hernández-Rodríguez, C. (2013). Nitrogen-fixing and uricolytic bacteria associated with the gut of Dendroctonus rhizophagus and Dendroctonus valens (Curculionidae: Scolytinae). Microb. Ecol. 66, 200-210. doi: 10.1007/s00248-013-0206-3

Mullins, D. E., and Cochran, D. G. (1975). Nitrogen metabolism in the american cockroach-I. An examination of positive nitrogen balance with respect to uric acid stores. Comp. Biochem. Physiol. A Physiol. 50, 489-500.

Nasir, H., and Noda, H. (2003). Yeast-like symbiotes as a sterol source in anobiid beetles (Coleoptera, Anobiidae): possible metabolic pathways from fungal sterols to 7-dehydrocholesterol. Arch. Insect Biochem. Physiol. 52, 175-182. doi: 10.1002/arch.10079

Ondov, B. D., Bergman, N. H., and Phillippy, A. M. (2011). Interactive metagenomic visualization in a Web browser. BMC Bioinformatics 12:385. doi: 10.1186/1471-2105-12-385

Pankewitz, F., Zöllmer, A., Hilker, M., Gräser, Y., Anja, Z., and Gräser, Y. (2007). Presence of Wolbachia in insect eggs containing antimicrobially active anthraquinones. Microb. Ecol. 54, 713-721. doi: 10.1007/s00248-007-9230-5

Pant, R. (1988). Nitrogen excretion in insects. Proc. Anim. Sci. 97, 379-415.

Patiño-Navarrete, R., Piulachs, M.-D., Belles, X., Moya, A., Latorre, A., and Peretó, J. (2014). The cockroach Blattella germanica obtains nitrogen from uric acid through a metabolic pathway shared with its bacterial endosymbiont. Biol. Lett. 10, 7-10. doi: 10.1098/rsbl.2014.0407

Pérez, J., Infante, F., Vega, F. E., Holguín, F., Macías, J., Valle, J., et al. (2003). Mycobiota associated with the coffee berry borer (Hypothenemus hampei) in Mexico. Mycol. Res. 107, 879-887. doi: 10.1017/S0953756203007986

Perez-Guerra, G., and Kosztarab, M. (1992). Biosystematics of the family dactylopiidae (Homoptera: Coccinea) with emphasis on the life cycle of Dactylopius coccus Costa. Bull. Virginia Agric. Exp. Stn. 92, 1-90.

Pérez-Ramirez, A., Castrejón-Ayala, F., and Jiménez-Pérez, A. (2014). Potential of terpenoids and mealybug extract to determine the establishment of Dactylopius opuntiae (Hemiptera: Dactylopiidae) crawlers on Opuntia ficus-indica. Florida Entomol. 97, 269-271.

Posada, D. (2008). jModelTest: phylogenetic model averaging. Mol. Biol. Evol. 25, 1253-1256. doi: 10.1093/molbev/msn083

Potrikus, C. J., and Breznak, J. A. (1980). Uric acid-degrading bacteria in guts of termites [Reticulitermes flavipes (Kollar)]. Appl. Environ. Microbiol. 40, 117-124.

Potrikus, C. J., and Breznak, J. A. (1981). Gut bacteria recycle uric acid nitrogen in termites: a strategy for nutrient conservation. Proc. Natl. Acad. Sci. U.S.A. 78, 4601-4605.

Powell, M. J. (1993). Looking at mycology with a Janus Face: a glimpse at Chytridiomycetes active in the environment. Mycologia 85, 1-20.

Ramírez-Puebla, S. T., Rosenblueth, M., Chávez-Moreno, C. K., Catanho Pereira de Lyra, M. C., Tecante, A., and Martínez-Romero, E. (2010). Molecular phylogeny of the genus Dactylopius (Hemiptera: Dactylopiidae) and identification of the symbiotic bacteria. Environ. Entomol. 39, 1178-1183. doi: 10.1016/j.syapm.2015.05.005

Ramírez-Puebla, S. T., Servín-Garcidueñas, L. E., Ormeño-Orrillo, E., VeraPonce de León, A., Rosenblueth, M., Delaye, L., et al. (2015). Species in Wolbachia? Proposal for the designation of "Candidatus Wolbachia bourtzisii", "Candidatus Wolbachia onchocercicola", "Candidatus Wolbachia blaxteri”, "Candidatus Wolbachia brugii”, "Candidatus Wolbachia taylori”, "Candidatus Wolbachia collembolicola”. Syst. Appl. Microbiol. 38, 390-399. doi: 10.1016/j.syapm.2015.05.005

Rho, M., Tang, H., and Ye, Y. (2010). FragGeneScan: predicting genes in short and error-prone reads. Nucleic Acids Res. 38, e191. doi: 10.1093/nar/gkq747

Ricci, I., Mosca, M., Valzano, M., Damiani, C., Scuppa, P., Rossi, P., et al. (2011). Different mosquito species host Wickerhamomyces anomalus (Pichia anomala): perspectives on vector-borne diseases symbiotic control. Antonie Van Leeuwenhoek 99, 43-50. doi: 10.1007/s10482-010-9532-3

Rivera, F. N., González, E., Gómez, Z., López, N., Hernández-Rodríguez, C., Berkov, A., et al. (2009). Gut-associated yeast in bark beetles of the genus Dendroctonus Erichson (Coleoptera: Curculionidae: Scolytinae). Biol. J. Linn. Soc. 98, 325-342. doi: 10.1111/j.1095-8312.2009.01289.x

Rodríguez, L. C., Faúndez, E., Seymour, J., Escobar, C. A., Espinoza, L., Petroutsa, M., et al. (2005). Factores bióticos y concentración de ácido carmínico en la cochinilla (Dactylopius coccus Costa) (Homoptera: Dactylopiidae). Agric. Técnica 65, 323-329. doi: 10.4067/s0365-28072005000300011

Rosas-Pérez, T., Rosenblueth, M., Rincón-Rosales, R., Mora, J., and MartínezRomero, E. (2014). Genome sequence of "Candidatus Walczuchella monophlebidarum" the flavobacterial endosymbiont of Llaveia axin axin (Hemiptera: Coccoidea: Monophlebidae). Genome Biol. Evol. 6, 714-726. doi: 10.1093/gbe/evu049 
Sasaki, T., Kawamura, M., and Ishikawa, H. (1996). Nitrogen recycling in the brown planthopper, Nilaparvata lugens: involvement of yeast-like endosymbionts in uric acid metabolism. J. Insect Physiol. 42, 125-129.

Schindelin, J., Arganda-Carreras, I., Frise, E., Kaynig, V., Longair, M., Pietzsch, T., et al. (2012). Fiji: an open-source platform for biological-image analysis. Nat. Methods 9, 676-682. doi: 10.1038/nmeth.2019

Schloss, P. D., Westcott, S. L., Ryabin, T., Hall, J. R., Hartmann, M., Hollister, E. B., et al. (2009). Introducing mothur: open-source, platformindependent, community-supported software for describing and comparing microbial communities. Appl. Environ. Microbiol. 75, 7537-7541. doi: 10.1128/AEM.01541-09

Scorzetti, G., Fell, J. W., Fonseca, A., and Statzell-Tallman, A. (2002). Systematics of basidiomycetous yeasts: a comparison of large subunit D1/D2 and internal transcribed spacer rDNA regions. FEMS Yeast Res. 2, 495-517. doi: 10.1111/j.1567-1364.2002.tb00117.x

Spodek, M., Ben-Dov, Y., Protasov, A., Carvalho, C. J., and Mendel, Z. (2013). First record of Dactylopius opuntiae (Cockerell) (Hemiptera: Coccoidea: Dactylopiidae) from Israel. Phytoparasitica 42, 377-379. doi: 10.1007/s12600013-0373-2

Stintzing, F. C., and Carle, R. (2005). Cactus stems (Opuntia spp.): a review on their chemistry, technology, and uses. Mol. Nutr. Food Res. 49, 175-194. doi: 10.1002/mnfr.200400071

Su, X., Pan, W., Song, B., Xu, J., and Ning, K. (2014). Parallel-META 2.0: enhanced metagenomic data analysis with functional annotation, high performance computing and advanced visualization. PLoS ONE 9:e89323. doi: 10.1371/journal.pone.0089323

Suh, S.-O., Nguyen, N. H., and Blackwell, M. (2008). Yeasts isolated from plant-associated beetles and other insects: seven novel Candida species near Candida albicans. FEMS Yeast Res. 8, 88-102. doi: 10.1093/oxfordjournals.molbev.a003901

Suh, S. O., Noda, H., and Blackwell, M. (2001). Insect symbiosis: derivation of yeast-like endosymbionts within an entomopathogenic filamentous lineage. Mol. Biol. Evol. 18, 995-1000. doi: 10.1093/oxfordjournals.molbev.a003901

Vega, F., and Blackwell, M. (2005). Insect-Fungal Associations: Ecology and Evolution. New York, NY: Oxford University Press. Available at: http://fmedicine.ajums.ac.ir/_fmedicine/documents/Insect fungal associations ecology and evolution_20130423_101512.pdf (Accessed August 15, 2014).

Zacchi, L., and Vaughan-Martini, A. (2003). Distribution of three yeast and yeast-like species within a population of soft scale insects (Saissetia oleae) as a function of developmental age. Ann. Microbiol. 53, 43-46.

Zimmermann, H. G., and Moran, V. C. (1991). Biological control of prickly pear, Opuntia ficus-indica (Cactaceae), in South Africa. Agric. Ecosyst. Environ. 37, 29-35. doi: 10.1016/0167-8809(91)90137-M

Conflict of Interest Statement: The authors declare that the research was conducted in the absence of any commercial or financial relationships that could be construed as a potential conflict of interest.

Copyright (C) 2016 Vera-Ponce de León, Sanchez-Flores, Rosenblueth and MartínezRomero. This is an open-access article distributed under the terms of the Creative Commons Attribution License (CC BY). The use, distribution or reproduction in other forums is permitted, provided the original author(s) or licensor are credited and that the original publication in this journal is cited, in accordance with accepted academic practice. No use, distribution or reproduction is permitted which does not comply with these terms. 